

\section{Transmission Cost Allocation Methodologies for Regional Transmission Organizations}

\section{July 2010}

Sari Fink, Jennifer Rogers, and Kevin Porter Exeter Associates, Inc.

Columbia, Maryland

NREL Technical Monitor: Erik Ela

Prepared under Subcontract No. LAM-9-99431-01

Subcontract Report NREL/SR-550-48738

July 2010

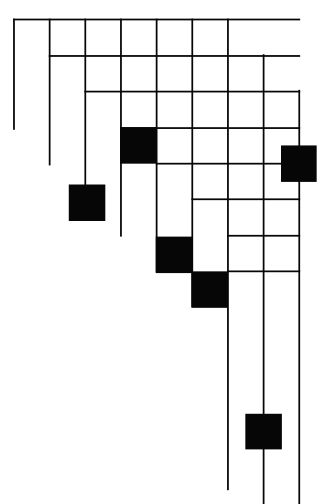




\section{NOTICE}

This report was prepared as an account of work sponsored by an agency of the United States government. Neither the United States government nor any agency thereof, nor any of their employees, makes any warranty, express or implied, or assumes any legal liability or responsibility for the accuracy, completeness, or usefulness of any information, apparatus, product, or process disclosed, or represents that its use would not infringe privately owned rights. Reference herein to any specific commercial product, process, or service by trade name, trademark, manufacturer, or otherwise does not necessarily constitute or imply its endorsement, recommendation, or favoring by the United States government or any agency thereof. The views and opinions of authors expressed herein do not necessarily state or reflect those of the United States government or any agency thereof.

Available electronically at http://www.osti.gov/bridge

Available for a processing fee to U.S. Department of Energy and its contractors, in paper, from:

U.S. Department of Energy

Office of Scientific and Technical Information

P.O. Box 62

Oak Ridge, TN 37831-0062

phone: 865.576 .8401

fax: 865.576 .5728

email: mailto:reports@adonis.osti.gov

Available for sale to the public, in paper, from:

U.S. Department of Commerce

National Technical Information Service

5285 Port Royal Road

Springfield, VA 22161

phone: 800.553 .6847

fax: 703.605.6900

email: orders@ntis.fedworld.gov

online ordering: http://www.ntis.gov/ordering.htm

This publication received minimal editorial review at NREL 


\title{
Transmission Cost Allocation Methodologies for Regional Transmission Organizations
}

\author{
A summary of RTO transmission cost allocation methodologies. \\ Information compiled through June 2010
}

This table describes transmission cost allocation methodologies for transmission projects developed to maintain or enhance reliability, to interconnect new generators, or to access new resources and enhance competitive bulk power markets, otherwise known as economic transmission projects.

In general, but not always, the costs of new or updated transmission needed to maintain reliability are assigned to load. Cost allocation for new or upgraded transmission for economic purposes may have to meet an economic test, such as lower projected production costs, although this varies by independent system operator (ISO) or regional transmission organization (RTO).

Cost allocation of new or upgraded transmission to interconnect new generators in the United States is largely dictated by FERC Order No. 2003. ${ }^{1}$ Order 2003 identifies two types of construction costs that are associated with generation interconnection: direct connection facilities and network transmission upgrades. Direct connection facilities include all equipment and construction required to connect the new generating facility to the first point of interconnection with the transmission grid, while network transmission upgrades include the equipment and construction required to reinforce or upgrade the existing transmission system in order to accommodate the new generation project.

Under Order 2003, generators are responsible for the cost of all direct connection facilities between the generator and the transmission grid, and must provide the funding for the cost of any network upgrades and new additions to the transmission network that are required as a result of the interconnection. Order 2003 states, however, that generators are to be fully reimbursed for the network upgrade costs by transmission providers within five years, with interest, in the form of either credits against the costs of transmission service or financial transmission rights if they are available.

By virtue of being considered independent entities by FERC in Order 2003, RTOs and ISOs are permitted to propose variations to the generator interconnection procedures contained within Order 2003, provided the proposals are "just and reasonable and not unduly discriminatory and would accomplish the purposes of Order 2003."2 Some RTOs and ISOs have used the

\footnotetext{
${ }^{1}$ Federal Energy Regulatory Commission, Order No. 2003, Standardization of Generator Interconnection Agreements and Procedures, Aug. 19, 2003, Order No. 2003-A, Mar. 26, 2004, Order No. 2003-B, Jan. 4, 2005.

${ }^{2}$ Federal Energy Regulatory Commission, Interconnection Queuing Practices, Order on Technical Conference, 122 FERC \ 61,252 (2008), p. 13, note 10.
} 
independent entity variation to propose alternative cost allocation methodologies for transmission upgrades and for interconnecting new generators, and it is these individual methodologies that are explored in this table.

FERC recently approved anchor/tenant-type cost allocation methodologies for two merchant transmission lines. TransCanada's Zephyr and Chinook projects are two 500-kV high-voltage direct-current transmission lines each with a capacity of 3,000 MW. The Zephyr project would originate in Wyoming while the Chinook project would originate in Montana, with both terminating in the Eldorado Valley south of Las Vegas. In February 2009, FERC granted both projects negotiated rate authority. TransCanada developed a precedent agreement for open seasons that were launched on October 13, 2009. The open seasons resulted in signed precedent agreements for the full 3,000 MW of available capacity on the Zephyr power transmission line with three renewable energy developers in Wyoming.

As this table was being finalized, FERC issued a proposed rule in June 2010 that would require each transmission provider to participate in a regional grid planning process and to study transmission that may be required to meet state or federal policy requirements such as renewable energy standards. The proposed rule would also require the transmission provider to create a grid planning agreement with each neighboring region. 
Table: RTO Transmission Cost Allocation for Reliability and Economic Transmission Projects

\begin{tabular}{|c|c|c|c|c|c|c|c|}
\hline & CAISO & ERCOT & ISO-NE & MISO & NYISO & PJM & SPP \\
\hline $\begin{array}{l}\text { Reliability } \\
\text { Upgrades }\end{array}$ & $\begin{array}{l}\text { Participating } \\
\text { transmission } \\
\text { owners finance } \\
\text { reliability } \\
\text { upgrades and are } \\
\text { repaid through } \\
\text { Transmission } \\
\text { Access Charges } \\
\text { (TAC) assessed to } \\
\text { CAISO grid users. } \\
\text { Costs of upgrades } \\
\geq 200 \text { kV allocated } \\
\text { to load on a MWh } \\
\text { basis. } \\
\text { Costs of merchant } \\
\text { transmission } \\
\text { facilities are } \\
\text { allocated to the } \\
\text { project sponsor, } \\
\text { which may } \\
\text { receive } \\
\text { repayment } \\
\text { through the TAC } \\
\text { or congestion } \\
\text { revenue rights. }\end{array}$ & $\begin{array}{l}\text { ERCOT } \\
\text { conducts a } \\
\text { system-wide } \\
\text { assessment } \\
\text { and the cost } \\
\text { allocation is } \\
\text { the same for } \\
\text { both reliability } \\
\text { and economic } \\
\text { projects. Costs } \\
\text { allocated } \\
\text { across all loads } \\
\text { based on } \\
\text { share of } \\
\text { summer peak } \\
\text { demand. }\end{array}$ & $\begin{array}{l}\text { Reliability } \\
\text { Upgrades } \\
\text { included in ISO- } \\
\text { NE Regional } \\
\text { System Plan as } \\
\text { needed to } \\
\text { ensure } \\
\text { reliability. } \\
\text { Regional } \\
\text { Benefit } \\
\text { Upgrades are } \\
\text { 115 kV and } \\
\text { above; costs } \\
\text { allocated to } \\
\text { load based on } \\
\text { zonal monthly } \\
\text { coincident peak } \\
\text { loads. Localized } \\
\text { costs excluded } \\
\text { from the } \\
\text { regional } \\
\text { allocation- } \\
\text { those costs } \\
\text { allocated only } \\
\text { to the zone in } \\
\text { which the } \\
\text { localized costs } \\
\text { were incurred. } \\
\text { Local Benefit } \\
\text { Upgrades are } \\
115 \text { kV and } \\
\text { below; costs } \\
\text { allocated locally } \\
\text { to the zone. }\end{array}$ & $\begin{array}{l}\text { Baseline Reliability } \\
\text { Projects include } \\
\text { upgrades where costs } \\
>\$ 5 \text { million or are } 5 \% \\
\text { or more of the } \\
\text { Transmission Owner's } \\
\text { net plant. } \\
345 \text { kV or above - } \\
\text { costs allocated 20\% } \\
\text { regionally on a } \\
\text { postage stamp basis, } \\
80 \% \text { sub-regionally } \\
\text { based on electrical } \\
\text { proximity using Line } \\
\text { Outage Distribution } \\
\text { Factor (LODF) analysis. } \\
100 \text { kV to } 344 \text { kV - } \\
\text { costs allocated } 100 \% \\
\text { sub-regionally to } \\
\text { pricing zones based on } \\
\text { LODF analysis. } \\
\text { PJM/ Midwest ISO } \\
\text { cross-border } \\
\text { allocation based on } \\
\text { each RTO’s } \\
\text { contribution to the } \\
\text { constraint that } \\
\text { required the need for } \\
\text { the upgrade; then } \\
\text { within each RTO, done } \\
\text { as per the RTO’s } \\
\text { respective methods. }\end{array}$ & $\begin{array}{l}\text { Reliability planning } \\
\text { identified by the } \\
\text { NYISO } \\
\text { Comprehensive } \\
\text { Reliability Planning } \\
\text { Process. While } \\
\text { market-based } \\
\text { solutions are } \\
\text { preferred, if a } \\
\text { regulated backstop } \\
\text { solution is needed } \\
\text { it is paid for on a } \\
\text { beneficiary-pays } \\
\text { basis. Primary } \\
\text { beneficiaries - } \\
\text { zones identified as } \\
\text { those contributing } \\
\text { to the reliability } \\
\text { violation that the } \\
\text { project will } \\
\text { alleviate. Costs } \\
\text { allocated to zones } \\
\text { based on } \\
\text { contribution to } \\
\text { violation and to } \\
\text { load serving } \\
\text { entities (LSEs) } \\
\text { within each zone } \\
\text { on a load ratio } \\
\text { share (MWh) basis. }\end{array}$ & $\begin{array}{l}\text { Reliability } \\
\text { Upgrades included } \\
\text { in the Regional } \\
\text { Transmission } \\
\text { Expansion Plan } \\
\text { (RTEP): Backbone } \\
\text { Facilities: } \geq 500 \mathrm{kV} \text {, } \\
\text { costs allocated } \\
\text { 100\% to load } \\
\text { based on each } \\
\text { zone's share of } \\
\text { zonal non- } \\
\text { coincident peak } \\
\text { load; }<500 \mathrm{kV} \text { and } \\
\text { cost }<\$ 5 \text { million - } \\
\text { are allocated to } \\
\text { zone; cost } \geq \$ 5 \\
\text { million - direct } \\
\text { beneficiaries } \\
\text { identified and } \\
\text { allocated costs. } \\
\text { The cost allocation } \\
\text { method for } \\
\text { facilities } \geq 500 \mathrm{kV} \text { is } \\
\text { currently under } \\
\text { court-ordered } \\
\text { review in FERC } \\
\text { Docket No. EL05- } \\
121-006 . P J M / \\
\text { Midwest ISO cross- } \\
\text { border allocation } \\
\text { based on each } \\
\text { RTO's contribution } \\
\text { to the constraint } \\
\text { that required the } \\
\text { need for the } \\
\text { upgrade; then } \\
\text { within each RTO, } \\
\text { done as per the } \\
\text { RTO's respective } \\
\text { methods. }\end{array}$ & $\begin{array}{l}\text { Effective June 19, } \\
2010 \text {, the } \\
\text { Highway/Byway } \\
\text { cost allocation } \\
\text { system will apply to } \\
\text { new transmission } \\
\text { facilities identified } \\
\text { as Base Plan } \\
\text { Upgrades (BPU). } \\
\text { BPU's include both } \\
\text { reliability and } \\
\text { economic projects } \\
\text { approved by the } \\
\text { SPP Board of } \\
\text { Directors, including } \\
\text { priority EHV } \\
\text { projects and } \\
\text { projects arising } \\
\text { from SPP's } \\
\text { proposed } \\
\text { Integrated } \\
\text { Transmission } \\
\text { Planning (ITP) } \\
\text { process. } \\
\text { Highway: } \geq 300 k V . \\
\text { All costs allocated } \\
\text { regionally. } \\
\text { Byway: < } 300 \mathrm{kV.} \\
\text { All costs zonal for } \\
\text { projects <100 kV; } \\
\text { for projects above } \\
100 \text { kV and below } \\
300 \text { kV, } 1 / 3 \\
\text { allocated regionally } \\
\text { and } 2 / 3 \text { zonal. } \\
\text { determined } \\
\text { according to the } \\
\text { SPP pricing zones. }\end{array}$ \\
\hline
\end{tabular}




\begin{tabular}{|c|c|c|c|c|c|c|c|}
\hline & CAISO & ERCOT & ISO-NE & MISO & NYISO & PJM & SPP \\
\hline $\begin{array}{l}\text { Generator } \\
\text { Interconnection } \\
\text { Upgrades }\end{array}$ & $\begin{array}{l}\text { Studies and direct } \\
\text { interconnection } \\
\text { costs are funded } \\
\text { by the } \\
\text { interconnection } \\
\text { customer. } \\
\text { Upgrade costs are } \\
\text { funded by the } \\
\text { interconnection } \\
\text { customer subject } \\
\text { to reimbursement } \\
\text { by the } \\
\text { participating } \\
\text { transmission } \\
\text { owner within } 5 \\
\text { years. The } \\
\text { participating } \\
\text { transmission } \\
\text { owner is repaid } \\
\text { through the TAC, } \\
\text { which is allocated } \\
\text { to load on a MWh } \\
\text { basis. } \\
\text { Separate category } \\
\text { for Location } \\
\text { Constrained } \\
\text { Resource } \\
\text { Interconnection } \\
\text { Facilities (LCRI) in } \\
\text { designated areas. } \\
\text { Costs are } \\
\text { recovered } \\
\text { through the TAC } \\
\text { until generators } \\
\text { come on-line, } \\
\text { after which } \\
\text { generators pay a } \\
\text { pro rata share. }\end{array}$ & $\begin{array}{l}\text { Costs } \\
\text { allocated to } \\
\text { the } \\
\text { transmission } \\
\text { service } \\
\text { provider. }\end{array}$ & $\begin{array}{l}\text { Costs of } \\
\text { network } \\
\text { upgrades are } \\
\text { allocated to the } \\
\text { generator. If } \\
\text { ISO-NE } \\
\text { determines the } \\
\text { upgrade } \\
\text { provides } \\
\text { system-wide } \\
\text { benefits, then } \\
\text { costs are } \\
\text { allocated in the } \\
\text { same manner } \\
\text { as ISO-NE's } \\
\text { Reliability } \\
\text { Upgrades. }\end{array}$ & $\begin{array}{l}\text { Generators required } \\
\text { to pay } 100 \% \text { of } \\
\text { interconnection costs } \\
\text { to lines smaller than } \\
345 \mathrm{kV} \text {, and } 90 \% \text { of } \\
\text { network upgrades for } \\
\text { lines } 345 \mathrm{kV} \text { or } \\
\text { greater. The } \\
\text { remaining } 10 \% \text { will be } \\
\text { recovered system- } \\
\text { wide. } \\
\text { Separate category for } \\
\text { projects } \\
\text { interconnecting to } \\
\text { American } \\
\text { Transmission } \\
\text { Company LLC, } \\
\text { International } \\
\text { Transmission } \\
\text { Company, Michigan } \\
\text { Electric Transmission } \\
\text { Company, LLC, or ITC } \\
\text { Midwest LLC: } \\
\text { interconnection } \\
\text { customer is fully } \\
\text { refunded for their } \\
\text { upgrade costs from } \\
\text { the host transmission } \\
\text { owner. }\end{array}$ & $\begin{array}{l}\text { For Energy } \\
\text { Resource } \\
\text { Interconnection } \\
\text { Service, developer } \\
\text { is responsible for } \\
\text { the cost of the new } \\
\text { interconnection } \\
\text { facilities not } \\
\text { identified in the } \\
\text { NYISO's Annual } \\
\text { Transmission } \\
\text { Reliability } \\
\text { Assessment. } \\
\text { For Capacity } \\
\text { Resource } \\
\text { Interconnection } \\
\text { Service, the total } \\
\text { cost of the } \\
\text { upgrades for all the } \\
\text { projects in a Class } \\
\text { Year will be } \\
\text { allocated among } \\
\text { the projects based } \\
\text { on the pro rata of } \\
\text { each Class Year } \\
\text { project on the } \\
\text { required } \\
\text { transmission } \\
\text { system upgrades. } \\
\text { In both cases, the } \\
\text { developer is fully } \\
\text { responsible for all } \\
\text { attachment } \\
\text { facilities. }\end{array}$ & $\begin{array}{l}\text { The costs of } \\
\text { interconnection in } \\
\text { PJM are allocated } \\
\text { in full to } \\
\text { generators } \\
\text { according to their } \\
\text { projected system } \\
\text { impact as } \\
\text { determined } \\
\text { through a study } \\
\text { process. }\end{array}$ & $\begin{array}{l}\text { Generator } \\
\text { Interconnection } \\
\text { Network Upgrades } \\
\text { are direct assigned } \\
\text { to Interconnection } \\
\text { Customer at 100\% } \\
\text { of cost. } \\
\text { Interconnection } \\
\text { customer's } \\
\text { contribution } \\
\text { towards Network } \\
\text { Upgrades are } \\
\text { eligible for revenue } \\
\text { credits. }\end{array}$ \\
\hline
\end{tabular}




\begin{tabular}{|c|c|c|c|c|c|c|c|}
\hline & CAISO & ERCOT & ISO-NE & MISO & NYISO & PJM & SPP \\
\hline $\begin{array}{l}\text { Economic } \\
\text { Upgrades }\end{array}$ & $\begin{array}{l}\text { Economic } \\
\text { Upgrades } \\
\text { identified through } \\
\text { the planning } \\
\text { process are } \\
\text { financed in the } \\
\text { same manner as } \\
\text { Reliability } \\
\text { Upgrades. }\end{array}$ & $\begin{array}{l}\text { ERCOT } \\
\text { conducts a } \\
\text { system-wide } \\
\text { assessment } \\
\text { and the cost } \\
\text { allocation is } \\
\text { the same for } \\
\text { both reliability } \\
\text { and economic } \\
\text { projects. Costs } \\
\text { allocated } \\
\text { across all loads } \\
\text { based on } \\
\text { share of } \\
\text { summer peak } \\
\text { demand. }\end{array}$ & $\begin{array}{l}\text { Market } \\
\text { Efficiency } \\
\text { Transmission } \\
\text { Upgrades can } \\
\text { be included in } \\
\text { the ISO-NE } \\
\text { Regional } \\
\text { System Plan } \\
\text { (RSP) if } \\
\text { evaluated as } \\
\text { beneficial to } \\
\text { reducing bulk } \\
\text { power system } \\
\text { costs - if } \\
\text { included in the } \\
\text { RSP as a } \\
\text { planned } \\
\text { project, costs } \\
\text { allocated same } \\
\text { as for reliability } \\
\text { upgrades. If } \\
\text { not, costs } \\
\text { allocated to } \\
\text { project } \\
\text { sponsors. }\end{array}$ & $\begin{array}{l}\text { Regionally Beneficial } \\
\text { Projects } 345 \text { kV or } \\
\text { higher and costing } \\
\text { over } \$ 5 \text { million can } \\
\text { qualify as an economic } \\
\text { upgrade if it meets or } \\
\text { exceeds cost/benefit } \\
\text { test that increases } \\
\text { linearly over the } \\
\text { transmission planning } \\
\text { period. Costs allocated } \\
20 \% \text { regionally on a } \\
\text { postage-stamp basis, } \\
80 \% \text { to the three } \\
\text { Transmission Provider } \\
\text { Planning sub-regions } \\
\text { (West, Central, East) } \\
\text { as determined by } \\
\text { congestion-based } \\
\text { metrics (beneficiary } \\
\text { analysis, } 70 \% \text { based } \\
\text { on production cost } \\
\text { benefits, 30\% based } \\
\text { on expected LMP- } \\
\text { based load benefits. } \\
\text { Analysis determines } \\
\text { each sub-region's } \\
\text { benefit from the } \\
\text { upgrade, and costs } \\
\text { recovered on a } \\
\text { postage stamp basis } \\
\text { within each). } \\
\text { If a project can be } \\
\text { designated as both a } \\
\text { Regionally Beneficial } \\
\text { Project and a Baseline } \\
\text { Reliability Project, } \\
\text { costs are allocated as } \\
\text { a Regionally Beneficial } \\
\text { Project. }\end{array}$ & $\begin{array}{l}\text { To be eligible for } \\
\text { this allocation, the } \\
\text { projected benefit } \\
\text { of the project } \\
\text { (measured as the } \\
\text { savings in } \\
\text { statewide } \\
\text { production cost } \\
\text { with and without } \\
\text { the proposed } \\
\text { project) must } \\
\text { exceed the } \\
\text { estimated cost, as } \\
\text { measured over the } \\
\text { first ten years from } \\
\text { the proposed } \\
\text { commercial } \\
\text { operation date. } \\
\text { Total capital cost } \\
\text { must exceed } \\
\text { \$25 million, and a } \\
\text { super-majority of } \\
80 \% \text { or greater of } \\
\text { the identified } \\
\text { beneficiaries are } \\
\text { required to } \\
\text { approve the } \\
\text { project. For each } \\
\text { load zone that } \\
\text { would benefit from } \\
\text { a proposed } \\
\text { project, costs are } \\
\text { allocated based on } \\
\text { the zonal share of } \\
\text { total LMP energy } \\
\text { savings. Within } \\
\text { zones, costs } \\
\text { allocated by each } \\
\text { LSE's MWh share } \\
\text { of total energy. }\end{array}$ & $\begin{array}{l}\text { Costs of Economic } \\
\text { Upgrade } \\
\text { enhancements to } \\
\text { reliability-based } \\
\text { projects included } \\
\text { in RTEP that } \\
\text { reduce cost of } \\
\text { meeting load are } \\
\text { allocated the same } \\
\text { way as reliability } \\
\text { upgrades. For } \\
\text { projects that are } \\
<500 \mathrm{KV} \text { and } \\
\text { accelerate } \\
\text { completion of an } \\
\text { approved reliability } \\
\text { project, cost } \\
\text { allocation assigned } \\
\text { to zones based on } \\
\text { the reduction in } \\
\text { LMP payments if } \\
\text { there is at least } \\
10 \% \text { difference } \\
\text { between this } \\
\text { method and the } \\
\text { method for } \\
\text { reliability projects. } \\
\text { For new economic } \\
\text { transmission that is } \\
<500 \mathrm{KV} \text {, costs } \\
\text { allocated to zones } \\
\text { which have a } \\
\text { projected decrease } \\
\text { in load energy } \\
\text { payments and is } \\
\text { based on each } \\
\text { zone's pro rata } \\
\text { share of the } \\
\text { change in load } \\
\text { energy payment. }\end{array}$ & $\begin{array}{l}\text { Priority EHV } \\
\text { projects have been } \\
\text { designated BPU } \\
\text { and will be paid } \\
\text { regionally through } \\
\text { the } \\
\text { Highway/Byway } \\
\text { methodology. } \\
\text { Projects arising } \\
\text { through the ITP will } \\
\text { be allocated } \\
\text { according to } \\
\text { Highway/Byway. } \\
\text { ITP will integrate } \\
\text { both reliability and } \\
\text { economic study } \\
\text { systems and will } \\
\text { include an annual } \\
\text { reliability } \\
\text { assessment, a } \\
\text { triennial 10-year } \\
\text { midterm } \\
\text { assessment, and a } \\
\text { triennial } 20 \text {-year } \\
\text { long-term } \\
\text { assessment. } \\
\text { (Note: as of June } \\
2010, \text { SPP's ITP } \\
\text { FERC filing was still } \\
\text { pending.) }\end{array}$ \\
\hline
\end{tabular}




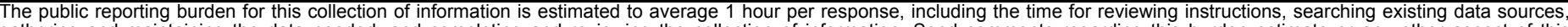

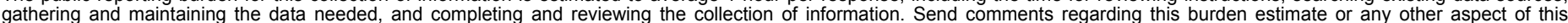

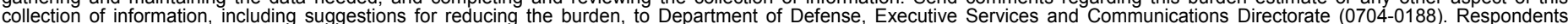

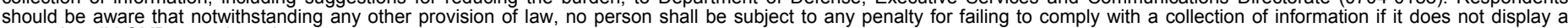

should be aware that notwithstanding

PLEASE DO NOT RETURN YOUR FORM TO THE ABOVE ORGANIZATION.

\begin{tabular}{l|l|l|l} 
1. REPORT DATE (DD-MM-YYYY) & 2. REPORT TYPE & 3. DATES COVERED (FrOm - TO)
\end{tabular} July 2010

Subcontract Report

4. TITLE AND SUBTITLE

Transmission Cost Allocation Methodologies for Regional

Transmission Organizations

5a. CONTRACT NUMBER

DE-AC36-08-GO28308

5b. GRANT NUMBER

5c. PROGRAM ELEMENT NUMBER

6. AUTHOR(S)

S. Fink, J. Rogers, and K. Porter

5d. PROJECT NUMBER

NREL/SR-550-48738

5e. TASK NUMBER

WE104311

5f. WORK UNIT NUMBER
7. PERFORMING ORGANIZATION NAME(S) AND ADDRESS(ES)

Exeter Associates, Inc.

10480 Little Patuxent Parkway, Suite 300

Columbia, MD 21044

9. SPONSORING/MONITORING AGENCY NAME(S) AND ADDRESS(ES)

National Renewable Energy Laboratory

1617 Cole Blvd.

Golden, CO 80401-3393
8. PERFORMING ORGANIZATION REPORT NUMBER

LAM-9-99431-01
10. SPONSOR/MONITOR'S ACRONYM(S) NREL

11. SPONSORING/MONITORING AGENCY REPORT NUMBER NREL/SR-550-48738

12. DISTRIBUTION AVAILABILITY STATEMENT

National Technical Information Service

U.S. Department of Commerce

5285 Port Royal Road

Springfield, VA 22161

13. SUPPLEMENTARY NOTES

NREL Technical Monitor: Erik Ela

14. ABSTRACT (Maximum 200 Words)

This report describes transmission cost allocation methodologies for transmission projects developed to maintain or enhance reliability, to interconnect new generators, or to access new resources and enhance competitive bulk power markets, otherwise known as economic transmission projects.

\section{SUBJECT TERMS}

Transmission; RTO; ISO; grid; independent system operator; RTO, regional transmission operator; utilities; cost allocation.

\begin{tabular}{l}
\hline 16. SECURITY CLASSIFICATION OF: \\
\begin{tabular}{|l|l|l|}
\hline $\begin{array}{l}\text { a. REPORT } \\
\text { Unclassified }\end{array}$ & Unclassified & Unclassified \\
& & \\
\hline
\end{tabular}
\end{tabular}

\begin{tabular}{|c|c|}
\hline $\begin{array}{l}\text { 17. LIMITATION } \\
\text { OF ABSTRACT }\end{array}$ & $\begin{array}{l}\text { 18. } \\
\text { OFUMBER } \\
\text { OFAGES }\end{array}$ \\
\hline UL & \\
\hline
\end{tabular}

19a. NAME OF RESPONSIBLE PERSON

19b. TELEPHONE NUMBER (Include area code) 